\section{Fra akutte til kroniske ryggsmerter}

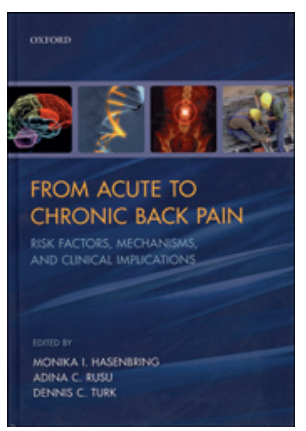

Monika I. Hasenbring, Adina C. Rusu,

Dennis C Turk, red.

From acute to chronic back pain

Risk factors, mechanisms, and clinical

implications. 590 s, tab, ill. Oxford: Oxford

University Press, 2012. Pris GBP 85

ISBN 978-0-19-955890-2

Tittelen henspiller på selve kjernen i behandlingen av vonde rygger: Mens nær $90 \%$ av de akutte vonde ryggene tilheler spontant, forblir 10-15\% som vedvarende, langvarige ryggsmerter. Det er disse som skaper problemer for den enkelte pasient, frustrasjon for behandlere og kostnader for samfunnet. Det er i overgangen fra akutt til langvarig ryggsmerte at innsatsen må settes inn.

Denne boken er intet mindre enn en oppsummering av de siste 20 årenes forskning på feltet. Redaktørene har ikke selv noen imponerende merittliste innen ryggforskning, men de har fått med seg $i$ alt 59 kompetente medforfattere som sørger for solid kunnskap i hvert kapittel. Foruten å gi en grundig innføring i både biologiske og psykologiske aspekter av ryggplager, viser forfatterne samlet mye av den kompleksiteten som langvarige ryggsmerter representerer.

Etter en epidemiologisk innledning diskuterer forfatterne først biologiske og biomekaniske mekanismer for smerter generelt og ryggsmerter spesielt. Vi blir oppdatert på ny forskning innen genetiske sammenhenger med ryggplager, endokrinologiske faktorer i sensitivisering og nevrofysiologiske perspektiver på smerteopplevelse.

Ryggmuskulaturen er en sentral smertegenerator for ryggplager, og basalforskningen knyttet til smerter fra ryggmuskulatur blir grundig omtalt.

I den biopsykososiale forståelsen av langvarige ryggsmerter er det likevel de psykologiske og sosiologiske forholdene som blir dominerende. Det er ikke til å unngå at det i ni kapitler som omhandler dette, blir en del gjentakelser. Det er likevel imponerende hvor bredt forfatterne favner, og de har fått med seg alt av nyere forskning.

De fem siste delene er rettet mot den kliniske bruken av forskningsresultatene. En lang rekke studier som beskriver legens rolle i behandlingen av ryggpasienter, retningslinjer, ryggskoler og mediekampanjer, farmakoterapi og subklassifisering av ryggpasienter, er alt sammen behørig og grundig omtalt. I de tre siste kapitlene beskriver forfatterne henholdsvis fysiske øvelser og trening, kognitiv atferdsterapi og rehabiliteringsprogrammer. Hvert kapittel avsluttes med en oppsummering av kunnskapen.

Det kan virke underlig at en så omfattende bok ikke har med et eneste avsnitt om kirurgisk behandling og heller ikke om bildediagnostisk utredning av ryggsmerter. En del mindre selvmotsigelser blir ikke problematisk, det bare viser at den absolutte sannhet når det gjelder de vonde ryggene ennå ikke er funnet.

Målgruppen er både klinikere og forskere. Boken er omfattende og grundig og bør være pensum for alle som behandler ryggpasienter i noe større omfang. De gode kildehenvisningene gjør den også godt egnet som oppslagsverk, spesielt med henblikk på forskning. Noen oppskrift for klinisk ryggbehandling får vi ikke. Budskapet er helt i tråd med norske og internasjonale retningslinjer og gir mange pekere mot ny, nødvendig forskning. Jeg har hygget meg godt med denne boken.

\section{Erik L. Werner}

Allmennmedisinsk forskningsenhet Bergen

\section{Den lille boken og det store emnet}

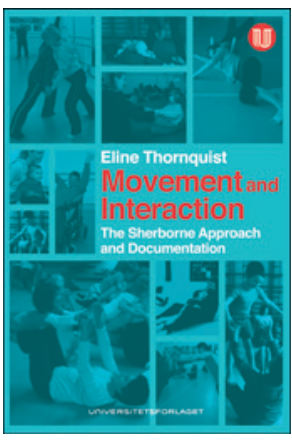

Eline Thornquist

\section{Movement and Interaction}

The Sherborne approach and documentation. 126 s. Oslo: Universitetsforlaget, 2012.

Pris NOK 239

ISBN 978-82-15-02035-8

Forfatteren er, som akademisk lærer, forsker, teoretiker og praktiker, en av de sentrale fagpersonene i norsk fysioterapi generelt og spesielt i den delen av faget som ble utviklet av norske behandlere i grenseflaten mellom nevrologi, fysikalsk medisin og fysioterapi, nemlig psykomotorisk fysioterapi. Hun kan kropp og bevegelse, og det ikke bare i betydningen av en oppgave for praktiserende terapeuter, men også som et felt for å generere ny kunnskap og å bygge adekvate teorier om menneskekroppens funksjon, bevegelse, og uatskillelig fra dette - om menneskers kroppslige samspill i det sosiale rom - interaksjon.

I en liten, men rik bok legger hun frem en todelt refleksjon. Den første delen gjelder bevegelse, og da i en spesiell form som er utviklet av Veronica Sherborne, en engelsk fysioterapeut, danser og lærer som utviklet «the Sherborne Developmental Movement» for å utforske og eksperimentere med bevegelser som antas å være grunnlaget for at vi kan stole på våre egne evner, det vi formår, og det vi kan. Dette handler om kroppen vi er, den som gjør mulig at vi vender oss til eller strekker oss mot andre mennesker, den som muliggjør interaksjon, den som gjør oss til handlende, til agenter. Denne kroppen står i sterk kontrast til den kroppen som mote- og treningsindustrien forteller oss at vi bør $h a$, den som skal formes, bygges, trenes, slankes eller styrkes og som er et objekt, en gjenstand for manipulasjon med bestemte typer fitness, form og proporsjoner som mål.

Den andre delen handler om menneskekroppen som uttrykksfelt for erfaring, og om dens meningsfylde, handlekraft og uttrykksevne som grunnleggende premisser for alt sosialt liv og menneskelig samvirke. Derfor handler den delen om hvordan bevegelse og interaksjon, kroppslig væren og sosialt liv, ikke kan skilles eller dokumenteres separat fordi kroppen er sentrum i alt sosialt liv. Fenomenologien, den filosofiske tradisjonen som fremstiller og oppfatter kroppen som forutsetning for all erfaring, er forfatterens referanseramme.

I denne lille boken drøftes altså et stort tema. Forfatteren utvider perspektivet på bevegelse i en tid da massemedier, faglitteratur og forskning tenderer til å redusere bevegelse til trening. Og selv om forfatteren retter oppmerksomheten mot et bestemt bevegelsessystem, skjer det på en måte som gjør budskapet allment relevant. Emnet «bevegelse», eller snarere mangel på bevegelse, har i de vestlige samfunn fått en helt sentral betydning for folkehelsen, men da oftest omtalt som «passiv livsførsel» eller «sedat livsstil».

Ut over dette påpeker forfatteren hvordan en fenomenologisk forståelsesramme gjør det mulig å utforske og å dokumentere bevegelse som forutsetning for sosialt liv ved å studere bevegelsespraksis og ved å dokumentere vanlige, daglige bevegelser i et lekent samspill hos og mellom mennesker.

En fortettet og velstrukturert bok om bevegelse som forutsetning for sosialitet, og om måter å utforske disse fenomenene på, er trolig for studerende $\mathrm{i}$ alle helsefag og særlig de av dem som vil begi seg inn i forskning, en ekte gave.

Anna Luise Kirkengen

Enhet for forskning

Akershus universitetssykehus 